\title{
Influence of Knowledge of IT and Self-Esteem among B.Ed Students
}

\author{
Navaneetham.S \\ P.hd., Scholar, Bharathiar University, Coimbathore.
}

\begin{abstract}
At present number of B.Ed colleges were established throughout the country. So a large mass of students undergone this course and study about teaching. Since they are the future teachers, the knowledge of IT will be very essential for them. Because in the modern scientific world everything will be improved with the help of computers, ie., the latest technology. By using various technologies in the classroom, teaching will be made effective and the students can easily understand the concepts. Self-esteem plays a vital role in every aspect of life, because it is the perception of his / her own. If one person think that he is a valuable person, then he can easily achieve his desires and goals. Good self-esteem induces self-confident and thus the performance will be more. This study will help to identify the influence of knowledge of IT and the self-esteem among the B.Ed students.
\end{abstract}

Key words: Self-Esteem, IT, ICT, B.Ed., Colleges, Madurai

\section{Introduction}

The concept of education is like a diamond which appears to be of different colour (nature) when seen from different angles (point of view). Commonly, education is any process, formal or informal, that helps to develop the potentialities of human beings, including their knowledge, capabilities, behavior patterns and values. Education is the creation of sound mind in a sound body. Education brings all round and harmonious development of the personality of an individual such as physical, intellectual, aesthetic, social, economic, religious, cultural, spiritual and through such development of individual social needs can be realized. A man without education is equal to animal. Education is an unique investment in the present and future. This cardinal principle is the key to the National policy of Education (1986). An individual starts learning as soon as he/she is born and the process continues until death. Education specifically refers to a process of learning. Education can be provided formally or non formally. Anyhow formal education is given more importance, in which education is provided through the schools, by the teachers, to the students. Thus, in the formal education teachers play an important role or in other words, we can say that without teachers there is no formal education.

\section{Self-Esteem}

Self-Esteem consists of two words 'Self' and 'Esteem'. Self is the core of personality, otherwise called the ego. It is the sum total of the personal awareness of the person himself. The interests and values with which he identifies himself along with his social perceptions are central to the self of the person. Esteem is defined as appreciation, worth, estimate of value. Thus, self-esteem is the package of belief that you carry around in your head, that you have accepted to be the trust about yourself, whether it is or not.

The term 'Self-Esteem' is one of the oldest concepts in psychology, have been first coined by the American psychologist and philosopher William James in 1890. It is one's mental perception of his qualities, not physical features. Self-Esteem is defined in many ways by many psychologists. Generally self-esteem refers to how we feel about ourselves, ie., it is a subjective feeling of self-worth build from the respect and sense of worth reflected back on the person from significant others.

\section{Definitions of the Self-Esteem}

According to Nathaniel Branden's (1969), "Self-esteem is the experience of being competent to cope with the basic challenges of life and being worthy of happiness".

According to Coppersmith (1967), "Self-esteem is a personal judgment of worthiness that is expressed in the attitudes that individuals has towards himself. It is a subjective experience which the individual conveys to others by verbal reports and other overt expressive behaviors"

\section{Self-Esteem Needs}

Maslow described two kinds of esteem needs, the need for respect from others and the need for selfrespect. Self-esteem entails competence, confidence, mastery from others entails recognition, acceptance, status, and appreciation. When these needs are not met, as individual feels discouraged, weak and inferior. For most, 
the need for regard from other diminishes with age because it has been fulfilled and the need for self-regard becomes more important.

\section{Dimensions of Self-Esteem}

Self-esteem has six dimensions and described below.

\section{(i) Competency}

Competency means ability to evaluate and understand one's personal resources. This feeling reflects esteem boned on skills, talents and unique achievement.

\section{(ii) Global Self- Esteem}

It is the general appraisal of the self and is based on the evaluation of all parts of himself. A positive global selfesteem would be reflected in feelings such as 'I am a good person' or 'I respect myself.'

\section{(iii) Moral Self- Esteem}

It is the reflection of feeling as being honest, sincere, adhering to social values etc.

\section{(iv) Social-Esteem}

Encompasses the humans feeling about himself as a friend to others. He feels satisfied with his interaction and relationship with peers.

\section{(v) Family Self-Esteem}

Reflects his feelings about himself as a member of his family. A person who feels he is valued member of his family, who make his own unique contribution and secure love and respect from parents and siblings, will have a high positive self-esteem in this area.

(vi) Body and Physical Appearance

It is the body image as a contribution of physical appearance and capabilities. The way we look or the way we see ourselves play significant roles in shaping our self-esteem.

\section{Information Technology (It)}

Today computers and educational software have been introduced at all level of education. The developments in the application and dissemination of information technology have been changing the demand in education. Information explosion is taking place at a very fast rate. IT will increases the knowledge and it can easily travel across the world. In the new millennium, information is being treated as the most important resource, besides men, money, machine, material and time. IT is also often called ICT (Information and Communication Technology). ICT can change the teaching profession and it is important that this issue is addressed in teacher training. Teachers should be prepared to take full advantage of potentials of ICT, but not for the sake of technology itself. Besides that, the focus should lie on the learning process of the future, not on the past. This is a tough challenge for the teacher training institutes and no one can escape from this. This means that the teacher trainees have some knowledge about the new technologies.

UGC $\mathbf{X}^{\text {th }}$ plan rightly puts that we are in the age of ICT revolution. The information and communication network in universities and colleges would provide intranet and internet activities. The flow of information enable the teachers to access multimedia material for teaching. The ICT revolutions would provide unique solutions for enhancing the overall academic ambience in higher education, especially in teacher education throughout the country. The role of IT in teacher training should be considered in a large perspective. With this knowledge, the investigator decided to find out the level of knowledge of IT among the B.Ed students. As per the study, the term knowledge of IT doesn't refers to the deeper understanding and knowledge about the technology subjects, rather it refers to the basic or fundamentals about the computers, general information about the various software and the internet. Without the proper fundamental knowledge about these no one enter into the technology field. These three areas should pave the way to the technology. Thus, the researcher interested in knowing the level of knowledge in IT and the influence of IT on the academic achievement of the B.Ed students.

\section{Statement Of The Problem}

The problem is entitled as "Influence of Knowledge of IT and Self-Esteem among B.Ed Students.

\section{Objective Of The Study}

To find out whether there is any significant difference in the self esteem of B.Ed students.

2. To find out whether there is any significant difference in the knowledge of IT among the B.Ed students.

3. To find out whether there is any significant relationship between the knowledge of IT and self-esteem of B.Ed students.

Hypotheses

1. There is no significant difference in the self-esteem of B.Ed students with respect to Gender, Community, Religion and Subject. 
2 There is no significant difference in the knowledge of IT among the B.Ed students with respect to Gender, Age, Subject and Community.

3. There is no significant relationship between the knowledge of IT and self-esteem of B.Ed students with respect to Gender, Subject,

\section{Population}

The total B.Ed students of Madurai district, Tamilnadu, India are the population of the study.

Sample

Randomly selected 300 B.Ed students from six various B.Ed., colleges in Madurai district, Tamilnadu, India.

Tools used

The tools used for the study were,

i) Self-Esteem Inventory (Standardised by Dr.S.Karunanidhi)

ii) Information Technology Questionnaire (Prepared by the investigator)

\section{Statistics used}

The following statistical techniques were used for analyzing and interpreting the data.

i) t-test

ii) ANOVA test

iii) Pearson's product moment correlation

$\mathrm{H} 1.1$

There is no significant difference in the self-esteem of B.Ed students with respect to gender.

Table - Gender based self-esteem

\begin{tabular}{|l|l|l|l|l|}
\hline \multicolumn{1}{|c|}{ Gender } & Mean & SD & t- value & Remarks \\
\hline Male & 231.31 & 20.18 & \multirow{2}{*}{-3.41} & N.S. \\
\hline Female & 240.16 & 22.39 & & \\
\hline
\end{tabular}

The calculated t-value (-3.41) is lesser than the tabulated value (1.97) at 0.05 level of significance. Hence the null hypothesis is accepted. Thus, there is no significant difference between the male and female B.Ed students in their self-esteem.

H 1.2

There is no significant difference in the self-esteem of B.Ed students with respect to community.

Table - community based self-esteem

\begin{tabular}{|l|l|l|l|l|l|}
\hline Source & Sum of Squares & df & Variance & \multirow{2}{*}{ F-Value } & \multirow{2}{*}{ Remarks } \\
\hline Between & 205.32 & 2 & 102.66 & \multirow{2}{*}{0.21} & \multirow{2}{*}{ N.S. } \\
\hline Within & 145473.52 & 297 & 489.81 & & \\
\hline Total & 145678.84 & 299 & & \\
\hline
\end{tabular}

The calculated F-value (0.21) is lesser than the tabulated value (3.03) at 0.05 level of significance. Hence the null hypothesis is accepted. Thus, there is no significant difference in the self-esteem of B.Ed students with respect to community.

H 1.3

There is no significant difference in the self-esteem of B.Ed students with respect to religion.

Table - religion based self-esteem

\begin{tabular}{|l|l|l|l|l|l|}
\hline Source & Sum of Squares & df & Variance & F-value & Remarks \\
\hline Between & 2025.28 & 2 & 1012.64 & \multirow{2}{*}{ N.S. } \\
\cline { 1 - 4 } Within & 143653.56 & 297 & 483.68 & & \\
\hline Total & 145678.84 & 299 & & & \\
\hline
\end{tabular}

The calculated value (2.09) is lesser than the tabulated value (3.03) at 0.05 level of significance. Hence the null hypothesis is accepted. Thus, there is no significant difference in the self-esteem of B.Ed students with respect to religion.

H 1.4 
There is no significant difference in the self-esteem of B.Ed students with respect to subject.

Table - subject based self-esteem

\begin{tabular}{|l|l|l|l|l|}
\hline Subject & Mean & SD & t-value & Remarks \\
\cline { 1 - 3 } Arts & 234.87 & 23.98 & \multirow{2}{*}{-1.46} & \multirow{2}{*}{ N.S. } \\
\hline Science & 238.84 & 20.78 & & \\
\hline
\end{tabular}

The calculated t-value (-1.46) is lesser than the tabulated value (1.97) at 0.05 level of significance. Hence the null hypothesis is accepted. Thus, there is no significant difference in the self-esteem of B.Ed students with respect to subject.

H 2.1

There is no significant difference in the knowledge of IT among the B.Ed students with respect to the gender.

Table T-VALUE SHOWING THE SIGNIFICANT DIFFERENCE in KNOWLEDGE OF IT WITH RESPECT TO GENDER

\begin{tabular}{|l|l|l|l|l|}
\hline Gender & Mean & SD & t-value & Remarks \\
\hline Male & 11.18 & 5.04 & \multirow{2}{*}{-1.79} & \multirow{2}{*}{ N.S. } \\
\cline { 1 - 3 } Female & 12.27 & 4.64 & & \\
\hline
\end{tabular}

The calculated t-value (-1.79) is lesser than the tabulated value (1.96) at 0.05 level of significance. Hence the null hypothesis is accepted. Thus, there is no significant difference in the knowledge of IT among the B.Ed students with respect to the gender.

$\mathrm{H} 2.2$

There is no significant difference in the knowledge of IT B.Ed students with respect to their age.

Table T-VALUE SHOWING THE SIGNIFICANT DIFFERENCE in KNOWLEDGE OF IT WITH RESPECT TO AGE

\begin{tabular}{|l|l|l|l|l|}
\hline \multicolumn{1}{|c|}{ Age } & Mean & SD & t-value & Remarks \\
\hline$\geq 23$ & 12.53 & 4.89 & \multirow{2}{*}{0.99} & \multirow{2}{*}{ N.S. } \\
\hline Above 23 & 11.80 & 4.76 & & \\
\hline
\end{tabular}

The calculated t-value (0.99) is lesser than the tabulated value (1.96) at 0.05 level of significance. Hence the null hypothesis is accepted. Thus, there is no significant difference in the knowledge of IT of B.Ed students with respect to their age.

H 2.3

There is no significant difference in the knowledge of IT among the B.Ed students with respect to subject.

Table T-Value Showing Significant Difference In Knowledge Of It With Respect To Subject

\begin{tabular}{|l|l|l|l|l|}
\hline Subject & Mean & SD & t-value & Remarks \\
\hline Arts & 10.63 & 4.34 & \multirow{2}{*}{-3.82} & N.S. \\
\cline { 1 - 3 } Science & 12.70 & 4.88 & & \\
\hline
\end{tabular}

The calculated t-value (-3.82) is lesser than the tabulated value (1.96) at 0.05 level of significance. Hence the null hypothesis is accepted. Thus, there is no significant difference in the knowledge of IT among the B.Ed students with respect to subject.

H 2.4

There is no significant difference in the knowledge of IT among B.Ed students with respect to community. Table - anova showing significant difference in knowledge of IT with respect to community

\begin{tabular}{|l|l|l|l|l|l|}
\hline \multicolumn{1}{|c|}{ Source } & Sum of Squares & df & Variance & F-value & Remarks \\
\hline Between & 14.41 & 2 & 7.20 & \multirow{2}{*}{0.31} & \multirow{2}{*}{ N.S. } \\
\cline { 1 - 4 } Within & 6837.98 & 297 & 23.02 & & \\
\hline Total & 6852.39 & 299 & & & \\
\hline
\end{tabular}


The calculated F-value (0.31) is lesser than the tabulated value (3.03) at 0.05 level of significance. Hence the null hypothesis is accepted. Thus, there is no significant difference in the knowledge of IT among B.Ed students with respect to community. H 3.1

There is no significant relationship between the knowledge of IT and self-esteem of B.Ed students with respect to gender.

Table - correlation between self-esteem and knowledge of IT With Respect To gender

\begin{tabular}{|l|l|l|l|l|l|l|l|}
\hline \multicolumn{1}{|c|}{ Gender } & $\Sigma \mathrm{X}$ & $\Sigma \mathrm{Y}$ & $\sum \mathrm{X}^{2}$ & $\Sigma \mathrm{Y}^{2}$ & $\sum \mathrm{XY}$ & r-value & Remarks \\
\hline Male & 21974 & 1062 & 5120984 & 14262 & 245540 & -0.011 & N.S \\
\hline Female & 49233 & 2516 & 11926151 & 35264 & 604772 & 0.025 & N.S \\
\hline
\end{tabular}

The calculated $r$-value $(-0.011)$ is lesser than the tabulated value $(0.196)$ at 0.05 level of significance. Therefore the null hypothesis is accepted. That is, there is no significant relationship between the knowledge of IT and Self-esteem of male B.Ed., students.

Similarly the calculated r-value (0.025) is lesser than the tabulated value (0.139) at 0.05 level of significance. Therefore the null hypothesis is accepted. That is, there is no significant relationship between the knowledge of IT and Self-esteem of female B.Ed., students.

H 3.2

There is no significant relationship between the knowledge of IT and self-esteem of B.Ed students with respect to subject.

Table - correlation between self-esteem and knowledge of IT With Respect To subject

\begin{tabular}{|l|l|l|l|l|l|l|l|}
\hline Subject & $\Sigma \mathrm{X}$ & $\Sigma \mathrm{Y}$ & $\sum \mathrm{X}^{2}$ & $\Sigma \mathrm{Y}^{2}$ & $\Sigma \mathrm{XY}$ & r-value & Remarks \\
\hline Arts & 26305 & 1190 & 6241965 & 14738 & 278349 & -0.099 & N.S \\
\hline Science & 44902 & 2388 & 10805170 & 34788 & 571963 & 0.085 & N.S \\
\hline
\end{tabular}

The calculated r-value (-0.099) is lesser than the tabulated value (0.196) at 0.05 level of significance. Therefore the null hypothesis is accepted. That is, there is no significant relationship between the knowledge of IT and Self-esteem among the arts subject B.Ed students.

Similarly we can say that there is no significant relationship between the knowledge of IT and selfesteem among the science subject B.Ed., students, since the calculated r-value (0.085) is lesser than the tabulated value $(0.139)$ at 0.05 level of significance.

\section{Major Findings Of The Study}

1. There is no significant difference in the self-esteem of B.Ed., students with respect to gender.

2. There is no significant difference in the self-esteem of B.Ed., students with respect to community.

3. There is no significant difference in the self-esteem of B.Ed., students with respect to religion.

4. There is no significant difference in the self-esteem of B.Ed., students with respect to subject.

5. There is no significant difference in the knowledge of IT among B.Ed., students with respect to gender.

6. There is no significant difference in the knowledge of IT among B.Ed., students with respect age.

7. There is no significant difference in the knowledge of IT among B.Ed., students with respect subject

8. There is no significant difference in the knowledge of IT among B.Ed., students with respect community

9. There is no significant relationship between the knowledge of IT and self-esteem of B.Ed., students with respect to gender.

10. There is no significant relationship between the knowledge of IT and self-esteem of B.Ed., students with respect to subject.

\section{Conclusion}

From the investigation we know that most of the B.Ed., students are in the average level in the knowledge of IT. To change this status, the knowledge of computers should be important among the children from the grass root level. Hence the curriculum developers and educational planners can take full effort in providing IT knowledge to the students. In order to implement these institutions can also give their support and suggestions. Theoretical as well as practical knowledge should be provided to the students. This will be done with the help of well trained and experts in the technology subject especially in the computer field.

From the analysis of the present study, it is inferred that most of the B.Ed., students having the average self-esteem. To improve their level of self-esteem parents and teachers can take necessary steps. Self respect, self values should be created among the students in order to develop the self-esteem. Multiple classroom 
opportunities should be provided in order to boost the self-esteem. The teachers should encourage their students to do the constructivist activities and appreciate them even if they failed to do well. This will help them to develop their self-confident as well as self-esteem. The motivation, flexibility, soft approach, caring of the teacher towards their students will also help a lot to improve the self-esteem.

Our present Indian education system more weightage is given to the percentage of marks obtained. But we have given the importance and much more weightage to students' interest towards life oriented education and providing a proper learning environment for construct a bright full nation.

\section{References}

[1] Arunagoel \& Goel, S.L (2005). Encyclopaedia of Higher Educationi in the 21 of century. Extension Education Services. New Delhi: Deep and Deep Publication.

[2] Bagulia, Abdul mannan (2004). Kothari Commission. New Delhi: Anmol Publications.

[3] Best, John W \& Khan, James V (2005). Research in Education (9 ${ }^{\text {th }}$ ed.). New Delhi: Prentice Hall of India Pvt Ltd.

[4] Dewan, Bhushan (2002). Managing Information Technology. New Delhi : Vikas Publishing House Pvt Ltd.

[5] Douglas, Mack R (1994). How to win with High Self-Esteem. New York: Longman.

[6] Garret, Henry E (2005). Statistics in Psychology and Education. New Delhi: Paragon International Publishers.

[7] Jain, Atal (2005). Computer in Education. New Delhi: Isha Books.

[8] Mohanty, Jagannath (2005). Educational Technology. New Delhi: Deep and Deep Publications Pvt. Ltd.

[9] Siddiqui, Mujibul Hasan (2004). Challenges of Educational Technology. New Delhi: APH Publishing Corporation.

[10] Siddiqui, Mujibul Hasan (2004). Encyclopaedia of Educational Technology (Vol.2). New Delhi: APH Publishing Corporation.

[11] Siddiqui, Mujibul Hasan (2004). Technology in Higher Education. New Delhi: APH Publishing Corporation.

[12] Zimbardo, Philip G \& Gerrig, Richard J (1999). Psychology and Life (15 ${ }^{\text {th }}$ ed.) New York: Longman. 